\title{
A nutritional assessment of children aged 1-3 years in the Greater Poland (Wielkopolska) region of Poland
}

\author{
Paulina Wojtyła-Buciora', Lucyna Kapka-Skrzypczak², Zuzanna Chęcińska-Maciejewska³ \\ Konrad Kozłowski ${ }^{4}$, Hanna Krauss' ${ }^{1}$ \\ 'Faculty of Health Sciences, the President Stanisław Wojciechowski State University of Applied Sciences in Kalisz, Poland \\ 2Department of Molecular Biology and Translational Research, Institute of Rural Health, Lublin, Poland \\ ${ }^{3}$ Department of Physiology, Poznan University of Medical Sciences, Poland \\ ${ }^{4}$ Faculty of Medical Sciences in Zabrze, Medical University of Silesia, Zabrze, Poland
}

\begin{abstract}
Introduction: Adequate nutrition is vital in infants and toddlers to ensure optimal development, both somatic and mental.

Aim of the study: To assess nutrition in children aged 13-36 months (toddlers), living in the Greater Poland region (Wielkopolska), according to their nutritional status and current nutritional recommendations. The relationship between anthropometric parameters (body mass and height) with nutritional status was also investigated in regard to WHO standards.

Material and methods: A questionnaire-based survey was conducted along with an assessment of the daily dietary intake. There were $n=520$ toddler subjects, aged 13-36 months, of whom $n=322$ were girls and $n=188$ were boys. The study was based on the subjects' present and previous nutritional behaviours in relation to current nutritional norms. Outcomes were also compared with centile charts prepared by the WHO. Data were statistically analysed using the SPSS-IBM software package, adopting $p<0.5$ as being statistically significant.

Results: Mothers breast fed their children in $78 \%$ of cases; however, such feeding was not exclusive in the first six months of life. Children were started on supplemented diets at various times during this period, at an average of 4.23 months. Overall, our study revealed poor dietary intake of milk, which is rich in unsaturated fatty acids and vitamin D. The dietary balance between vegetables and fruit was inappropriate. Furthermore, daily fluid intakes were quite markedly inadequate. Toddlers' mainly drank either water or sweetened fizzy/sparkling drinks (soda-pop). According to the centile charts, $15 \%$ were underweight, $71 \%$ had normal BMIs, $5 \%$ were overweight, and $8 \%$ were obese.

Conclusions: Promoting breast feeding should be treated as a public health priority because so few mothers exclusively do so in the first six months of their offspring's life. Nutrition in toddlers aged 13-36 months often differs from the recommended standard models, and thus medical-dietetic advice should always be designed to track and remedy this situation. Toddlers' diets therefore need to be modified whenever BMIs are abnormal so as to ensure that dietary intake has the required nutrient profiles necessary for adequate nutrition.
\end{abstract}

KEY WORDS: nutrition, children, dietary behaviour, BMI. 


\section{INTRODUCTION}

Adequate nutrition determines a toddler's (aged 1-3 years) normal physiological development. Achieving a normal body mass and height reduces the risk of diet-related diseases, such as: hypertension, a disrupted carbohydrate and lipid metabolism (so-called metabolic syndrome), type II diabetes, overweight, and obesity [1-7]. Due to abnormal nutritional behaviours and a lack of physical exercise, the global increases observed in overweight and obesity constitute one of the most important health issues facing the world. Epidemiological studies have shown that the rates of child and adolescent overweight have doubled over the last 25 years, whereas those for obesity have tripled [8]. An excessive body mass has been observed in Europe in around 20\% of children, of whom 5\% were obese [9-11]. In Poland, the corresponding rates are $15 \%$ for those overweight, of whom $2 \%$ are obese $[12,13]$.

During the first 1-3 years of life, the development of children's psychomotor abilities is most intensive, and thus their diets should be adequately balanced in terms of calories and nutrients. Foodstuffs introduced into children's diets by their parents/legal guardians, along with their consumption rates, do not always comply with EU recommendations nor those prepared domestically in Poland by the Institute of Food and Nutrition (IFN) [14-17]. Moreover, children do not, as a whole, uniformly reject newly introduced foodstuffs just because they taste different when compared to ones they are already familiar with. It is well recognised that frequently eaten foodstuffs at such an early age have an influence on how tastes develop and on later eating choices $[18,19]$.

The dietary behaviour of parents/legal guardians, as well as their knowledge base of adequate nutrition, also significantly affect their children's nutrition. Inappropriate dietary habits already acquired in childhood create disadvantageous nutritional behaviours that are often exacerbated whenever there is poverty and/or poor living conditions at home.

\section{AIM OF THE STUDY}

To assess nutrition in toddlers aged 13-36 months, who live in the Greater Poland region of Poland, according to:

- nutritional status and currently binding nutritional recommendations,

- selected anthropometric indicators (of body mass and height) according to World Health Organization (WHO) standards.

\section{MATERIAL AND METHODS}

A pilot survey-study by questionnaire was first conducted in March 2019 on 30 mothers and their 13-36-month-old children who were attending the "Profamilia" Paediatric Health Centre in Kozielgowy Town in the Greater Poland (Wielkopolska) region of Poland.
Subsequently, the main study used an amended form of the survey-questionnaire conducted in the same year from May to July, also at the same health centre, on a sample of 520 randomly selected children aged 1-3 years, together with their parents/legal guardians. There were 332 girls (64\%) and 188 boys (36\%), having an overall average age of 23.3 months. The proportions of subjects living in urban and rural areas were comparable: respectively, $52 \%$ and $48 \%$. There were $54 \%$ of parents with higher education obtained either at university or technical college, whereas $33 \%$ had upper-level secondary education, and $13 \%$ had lower-level secondary education or vocational education (Table 1).

For the study, a questionnaire developed in-house was used together with a diet-diary, which patients filled in daily with details of the types of foodstuffs consumed and their frequency. This was done during two days of a particular week and on one bank holiday (feast day). The questionnaire was completed by the parents/legal guardians in the presence of a study surveyor and consisted of three parts. Part one dealt with the socio-environmental conditions of family life. Part two was concerned with the anthropometric parameters of the child, such as body mass and height, which were obtained from the child's medical record book (Health Card), along with details of illnesses suffered and the type and duration of the actual childbirth. Part 3 was about the child's nutrition and their food preferences. The respons-

TABLE 1. Study group characteristics

\begin{tabular}{|c|c|c|}
\hline Variable & \multicolumn{2}{|c|}{$\begin{array}{c}\text { Toddlers aged 13-36 } \\
\text { months }(n=520)\end{array}$} \\
\hline $\begin{array}{l}\text { Toddler age in months } \\
\text { (mean } \pm \text { SD) }\end{array}$ & \multicolumn{2}{|c|}{$23.3 \pm 8.1$} \\
\hline \multicolumn{3}{|l|}{ Gender } \\
\hline Girls & \multicolumn{2}{|c|}{$64 \%(n=332)$} \\
\hline Boys & \multicolumn{2}{|c|}{$36 \%(n=188)$} \\
\hline \multicolumn{3}{|l|}{ Place of residence (\%) } \\
\hline City above 501,000 & \multicolumn{2}{|c|}{22} \\
\hline City $151-500,000$ & \multicolumn{2}{|c|}{15} \\
\hline City 51-150,000 & \multicolumn{2}{|c|}{5} \\
\hline Town up to 50,000 & \multicolumn{2}{|c|}{9} \\
\hline Village & \multicolumn{2}{|c|}{48} \\
\hline Parents' education (\%) & Mothers & Fathers \\
\hline Higher university degree & 45 & 36 \\
\hline $\begin{array}{l}\text { Higher technical college } \\
\text { degree }\end{array}$ & 18 & 9 \\
\hline Upper level secondary & 31 & 36 \\
\hline Vocational & 4 & 17 \\
\hline Lower level secondary & 2 & 2 \\
\hline
\end{tabular}


es thus obtained served to establish children's nutritional behaviour and how the parents fed their children.

Before starting the study, all participants were notified by the study surveyor that their inputs were taken as being both voluntary and anonymous.

Statistical analyses were performed using the IBMSPSS Statistics 23 package. The number sizes (mean and standard deviations) and proportions (rates) of each variable were thereby obtained. The significance of differences and any associations in nutritional behaviour between variables were assessed by summary statistics, the Kolmogorov-Smirnoff test, Spearman's Rank Correlation, the $\chi^{2}$ test, and the Fisher exact test; all taking $p<0.05$ as being significant.

\section{RESULTS}

Seventy eight percent of the children were breast fed. A worrying feature, however, was that none had been exclusively breast fed during the first six months.

Nutritional guidelines prepared by the IFN state that children should optimally eat 4-5 meals daily, taking into account the types of foodstuffs in their diet. Also considered are the daily frequency of foodstuff consumption as well as their qualitative and quantitative content [14]. Systematically eating five meals daily results in the body getting used to receiving an optimal intake of calories and nutrients to ensure appropriate metabolism. Our study showed that $78 \%$ of subjects ate $4-5$ meals daily, whilst one in five ate six or more daily meals; the latter running the risk of becoming overweight (Fig. 1).

Parents/legal guardians declared that they mainly prepared one-dish meals (79\%) as opposed to two-dish meals $(21 \%)$. Nevertheless, one in five parents took their

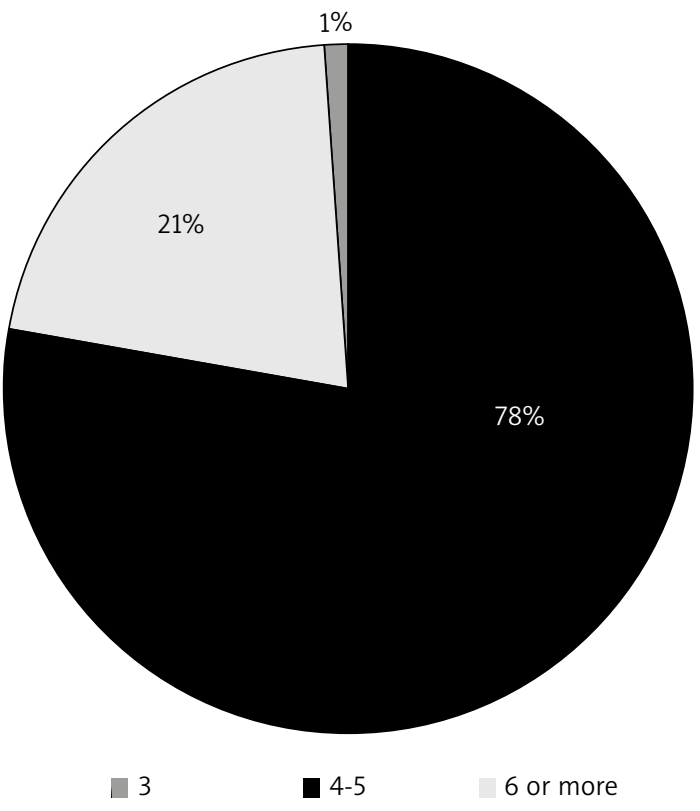

FIG. 1. Number of daily meals eaten by children, $p\left(\chi^{2}\right)<0.001$ children's eating preferences and age into account when preparing meals; in fact, over half did so whenever time permitted (Fig. 2).

We have also shown that parents widened the scope of their children's diets according to the stages of their development - within the age range of 4-7 months (mean 4.23 months), children were supplementarily fed with the following foodstuffs: fermented dairy products, eggs, poultry, red meat, cold meats, fish, fresh fruit, vegetables, and cereals.

Two daily portions of milk or dairy products are recommended, where milk can be partly replaced by one portion of fermented dairy products, such as yogurt, kefir, and cream/homogenised cheeses [14]. Our results demonstrated that the most frequently consumed dairy products were milk (39\%), natural yogurt (12\%), cheese (15\%), and cream cheese (20\%). Only $1 \%$, however, ate buttermilk or kefir.

Eggs are a good dietary source of protein and fat in children. They also contain many desirable vitamins (fat soluble: A, D, E, and K), minerals and lutein, which is responsible for normal eye function. A weekly dietary intake of 3-4 eggs is recommended (i.e. amounting to half an egg daily) [14]. Our study showed that $40 \%$ of the children ate one egg daily.

Children's diets should not lack meat nor cold meats, so as to ensure the body's requirement for complete (whole) protein. Almost half the parents gave their children meat from 4-5 times weekly; one in five did so daily. It should, however, be noted that $6 \%$ ate no meat at all, presumably because they were on vegetarian diets. Parents prepared the following meats most frequently: poultry $(94 \%)$, pork $(68 \%)$, beef $(44 \%)$, and rabbit

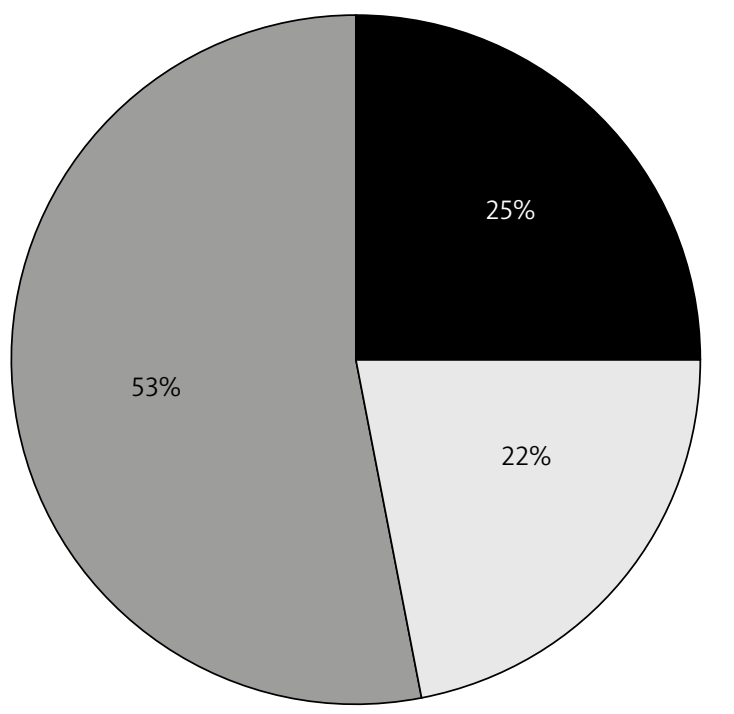

- Same meals eaten by family Child gets a separate meal Mixed (depending on time available)

FIG. 2. Breakdown of personalised meals eaten by children, $p\left(\chi^{2}\right)<0.001$ 
TABLE 2. Type and frequency of foodstuffs consumed by children (\%)

\begin{tabular}{|l|c|c|c|c|}
\hline \multirow{2}{*}{ Product type } & \multicolumn{4}{|c|}{ Frequency of consumption according to foodstuff type } \\
\cline { 2 - 5 } & Daily & $1-3$ times weekly & $4-5$ times weekly & Not eaten \\
\cline { 2 - 5 } & 18 & 32 & 44 & 6 \\
\hline Fish & Daily & Once a week & $2-3$ times weekly & Not eaten \\
\hline Dairy products & 1 & 63 & 14 & 22 \\
\hline Groats & 22 & 30 & 42 & 6 \\
\hline Fruit & 21 & 47 & 32 & 0 \\
\hline Vegetables & 86 & 4 & 11 & 0 \\
\hline Sweets (confectionery) & 76 & 5 & 19 & 0 \\
\hline$p\left(\mathrm{X}^{2}\right)<0.001$ & 12 & 42 & 36 & 10 \\
\hline
\end{tabular}

(25\%). Certain principles should be generally adopted in consuming these foodstuffs. Beef and pork should be replaced by skinless poultry and fish (especially sea fish). Fish should be baked or boiled and served to children 1-2 times weekly [14]. Our results showed that $63 \%$ of children ate fish once weekly, but only $14 \%$ did so 2-3 times weekly. Parents never giving their children fish comprised $14 \%$, which is a source of unsaturated omega-3 fatty acids.

One of the most common faults observed in children's diets is in the eating of sufficient vegetables. These should be eaten more frequently than fruit (in a recommended $3 / 4$ to $1 / 4$ ratio), because the latter contains more simple sugars and are more calorific [14]. Our study showed that this proportion was not adhered to; more fruit was eaten (84\%) than vegetables (76\%).

Children's diets were not also lacking in sweet snacks (confectionery). Sweets were eaten daily by $12 \%$, 3-4 times weekly by $42 \%$, and 2-3 times weekly by $36 \%$. Such outcomes could lead to nutritional deficiencies and overweight.

Another important foodstuff grouping in children's diets are cereals, which deliver complex carbohydrates, fibre, group B vitamins, and minerals. Furthermore, combining cereals with milk products improves the dietary intake of vegetable protein [14]. Diverse breads/ cereals are recommended in children' diets: wholegrain, white and brown bread, different types of coarse or fine groats, and porridge oats. We showed that $83 \%$ of children ate all kinds of cereal products, $13 \%$ ate wholemeal ones, and $4 \%$ ate those that were gluten-free (Table 2 ).

The different types of fats and oils that parents used for making sandwiches or cooking with were also determined. Most children ate buttered bread-sandwiches (72\%), whilst parents mainly used vegetable oils for cooking (56\%). Oil was used by $10 \%$ on sandwiches, whilst $15 \%$ of parents fried food without any oil/fat (Fig. 3).

A vital dietary component is the daily fluid intake. Drinking around $1300 \mathrm{~mL}$ of fluid daily is required for children aged 1-3 years [14]. Our findings show that $8 \%$ of children drank more than $1.5 \mathrm{~L}$ daily, $58 \%$ drank 1-1.5 L daily, but 35\% drank less than $1 \mathrm{~L}$ daily. Parents mainly gave water as the fluid (72\%) but also sweetened drinks like flavoured water (34\%), sugared tea $(68 \%)$, juices (54\%), and soda-pop (12\%).

Anthropometric measurements were used to assess children's nutritional status (body mass and height), which were provided by the parents/legal guardians from medical cards. If current data were unavailable, then such measurements were taken at the family's health centre. The BMIs were thereby determined $\left(\mathrm{kg} / \mathrm{m}^{2}\right)$ and referenced to centile charts of body mass and height. The WHO has defined the following BMI ranges: $<5^{\text {th }}$ centile as underweight, $\geq 5^{\text {th }}$ centile $<85^{\text {th }}$ centile as normal body mass/weight, $\geq 85^{\text {th }}$ centile $<95^{\text {th }}$ centile as overweight, and $\geq 95^{\text {th }}$ centile as obese [20].

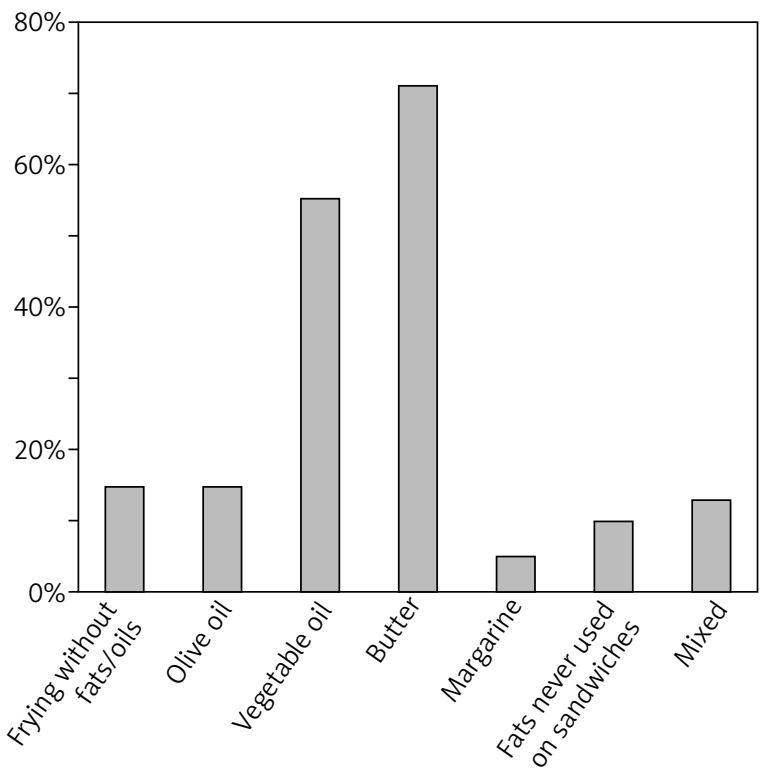

FIG. 3. A breakdown on the types of fats/oils used in preparing sandwiches and frying, $p\left(\chi^{2}\right)<0.001$ 
TABLE 3. Children's nutritional status according to centile charts

\begin{tabular}{|c|c|c|c|c|c|}
\hline \multirow{3}{*}{\multicolumn{2}{|c|}{ Group size }} & \multicolumn{4}{|c|}{ Children's nutritional status } \\
\hline & & $\begin{array}{c}\text { Underweight } \\
\text { children } \\
<5^{\text {th }} \text { centile }\end{array}$ & $\begin{array}{c}\text { Normal body } \\
\text { mass children } \\
\geq 5^{\text {th }} \text { centile } \\
<85^{\text {th }} \text { centile }\end{array}$ & $\begin{array}{l}\text { Overweight } \\
\text { children } \\
\geq 85^{\text {th }} \text { centile } \\
<95^{\text {th }} \text { centile }\end{array}$ & $\begin{array}{l}\text { Obese children } \\
\geq 95^{\text {th }} \text { centile }\end{array}$ \\
\hline & & $15 \%(n=80)$ & $71 \%(n=368)$ & $5 \%(n=28)$ & $8 \%(n=44)$ \\
\hline \multicolumn{2}{|c|}{ Average age (months) } & 22.75 & 22.84 & 26.64 & 26.18 \\
\hline \multirow{5}{*}{$\begin{array}{l}\text { Place } \\
\text { of residence }\end{array}$} & City above 501,000 & 24 & 68 & 12 & 32 \\
\hline & City $151,000-500,000$ & 8 & 56 & 4 & 12 \\
\hline & City $51,000-150,000$ & 4 & 12 & 8 & 4 \\
\hline & Town up to 50,000 & 12 & 28 & 0 & 8 \\
\hline & Village & 24 & 204 & 4 & 12 \\
\hline \multicolumn{2}{|l|}{$p\left(\chi^{2}\right)<0.001$} & $<0.001$ & $<0.001$ & $<0.001$ & $<0.001$ \\
\hline
\end{tabular}

We found that $71 \%$ of our subjects had normal BMI, whereas $15 \%$ were underweight. It should, however, be noted that we found higher rates of obesity (8\%) than overweight (5\%). There were also higher rates of normal BMI for those living in rural areas (countryside) than for city dwellers (Table 3).

\section{DISCUSSION}

Adequate nutrition after childbirth and during the first years of life are among the most vital factors that determine optimal development, both somatic and mental. Irreversible changes to metabolism and endocrine function are caused by adverse environmental factors, like deficient or excessive dietary intakes, which can be experienced during the most crucial times in human development. This model is defined as programmed nutrition focused on child-bearing and infant age [21] one of the related factors being breast feeding. The European Society for Paediatric Gastroenterology, Hepatology, and Nutrition (ESPGHAN) recommends that children should be exclusively fed on breast milk up to the sixth month $[17,22]$. Breast feeding should, however, continue afterwards with the cotemporaneous introduction of supplementary feeding. The correct amount and composition of breast milk ensures that the required calories and nutrients are supplied during the first six months of life. A mother's breast milk given in sufficient amounts by an adequately nourished mother fully satisfies the infant's demand for calories and all nutrients, which allows normal development in the first months of life [23-26]. Our study shows that $78 \%$ of mothers breast fed their offspring; however, it is of concern that none of the infants had exclusively received only their mother's breast milk. A study by the Mother and Child Institute showed that only $56 \%$ of children were breast fed during the first half year of life, of whom only one in five were exclusively breast fed [27].
The next dietary stage for infants is to broaden the scope. Foodstuffs other than milk or modified milk should be introduced from six months onwards. This is primarily because milk by itself becomes insufficient to meet the child's calorific demands, and the digestive and excretory systems at this time are ready to process other types of food [14]. Nevertheless, the parents' level of knowledge about broadening the scope of an infant's diet at this time does not concur with current standards. Our results demonstrate that parents broadened their children's diets between four to six months. This usually happened early; other foods had been introduced a mean of 4.23 months. Brazilian studies conducted on children aged 1-3 years found that the age when infants were given supplementary food was 5.3 months [28]. A USA cohort study showed that $40 \%$ of children received food other than breast milk at four months [29]. Likewise, a UK study found this to be the case also after a mean of four months [30].

It appears that our subjects received adequate nutrition in terms of the number of daily meals and how they were prepared (one or two dish meals). We showed that $78 \%$ of subjects who were not breast feeding ate 4-5 meals daily. Tailoring meals the suit the child's preferences was only possible when time allowed the parents/legal guardians to do so. A Poland-wide study found that children of the same age ate at least five meals daily [27].

Micro- and macro-nutrients constitute a vital part of an adequate diet for children. Our findings show that there are dietary deficiencies in the consumption of milk, dairy products, fish, and foods rich in unsaturated fatty acids. Milk and its products are an ideal source of calcium, protein, vitamins $\left(\mathrm{B}_{11}, \mathrm{~B}_{2}, \mathrm{~B}_{6}\right.$ and $\left.\mathrm{B}_{12}\right)$, folic acid, vitamin $\mathrm{A}$, and magnesium. Calcium is readily absorbed from milk products, and the recommended daily milk intake covers $60 \%$ of the calcium requirement [14]. 
The presented study shows that $39 \%$ subjects aged over 13 months drank milk daily. A Poland-wide study also showed such low levels of milk consumption when compared to standard models of adequate nutrition [27]. A child's diet should be rich in both animal fat (i.e. butter) and in vegetable and olive oils. We found that parents mostly served buttered sandwiches, whilst only $5 \%$ used margarine. Over half used vegetable oil for frying. Only $15 \%$ fried without any fat or oil. A PITNUTS study from 2016 showed that children consume $40 \%$ more trans-fats than the recommended intake of $11.1 \mathrm{~g} /$ day [27]. The low dietary amounts found of long-chain polyunsaturated fatty acids and vitamin $\mathrm{D}$ was because children ate fish rarely, and $22 \%$ never ate fish. Meat and its products replaced fish in the diet, which has also been confirmed in USA studies [31].

A complete daily diet for children should contain fruit and vegetables. These possess antioxidant properties, inhibit cell proliferation, regulate hormone action, and stimulate the immune system. Furthermore, every portion of fruit and vegetables delivers a wide range of bioactive compounds like carotenoids, vitamins $\mathrm{C}$ and $\mathrm{E}$, folic acid, selenium, flavonoids, and fibre [14]. Children's diets are rich in mainly simple sugars due to the fact that fruits are tasty and are keenly eaten by children, and thus they are more frequently given by parents. A study by Harton et al. on pre-school children showed a two-fold higher rate of fruit consumption compared to vegetables [32]. Similar findings were observed in the USA on 2 -3-year-olds, where $70 \%$ ate vegetables at least once daily, whereas $73 \%$ ate fruit as a separate foodstuff [33].

Similar outcomes to ours were observed in an Australian study, in which the majority of child subjects consumed recommended foodstuffs such as cereal products, meat or poultry, fruit, and vegetables. Nonetheless, there were increasing rates of children consuming energy-dense foodstuffs, particularly for those aged 9-18 months. They included sugary drinks and sweet snacks [34]. We found that $12 \%$ ate sweets daily, $42 \%$ did so $3-4$ times weekly, and 36\% 2-3 times weekly. Fox et al. indicated that $85 \%$ of children aged $2-3$ years drank sugary drinks and ate sweet desserts or snacks [33]. Other studies on children aged below two years have likewise found high consumption of these foodstuffs, which are poor in nutrients but high in calories [27, 31, 35, 36].

Maintaining an appropriate water-mineral balance is especially important in young children. Clean water intended for consumption by infants and toddlers should be naturally free of chemicals and micro-organisms, but it should have the necessary complement of minerals. Source and natural water are recommended for infants, as well as waters with low sodium and mineral content $[14,37]$. We found grave shortcomings in our results on children's water intake. Every third child drank less than $1 \mathrm{~L}$ of fluid daily. Moreover, parents declared that their children drank sugary drinks such as sugared tea, juices, and soda-pop. A study by Budnee et al. showed that $54 \%$ of one-year-olds drank sugary soda-pops daily [38]. Miles and Siege-Riz found that USA children aged 12-33 months drank sugary soda-pops [39].

We demonstrated abnormal body mass and height according to age. The most numerous group (71\%), however, had normal body mass conforming to accepted centile references. Underweight was seen in $15 \%$ of cases, whilst overweight or obesity in $13 \%$. Likewise, the aforementioned PINUTS study showed that $68 \%$ of subjects possessed a normal body mass, but they found disturbingly high rates of overweight and obesity: respectively, 25\% and 4\% [27]. Our study, however, observed a significantly higher proportion of children with normal BMIs than a study by Weker et al. (at only 46\%), although similar outcomes were seen in the numbers of overweight, at $13 \%$. However, the combined overweight and obesity rates were $28 \%$ [40].

The literature shows that the rapid rise in body mass at infancy affects the development of overweight and obesity in childhood [41]. All this demonstrates the need to check with recommendations that concern child nutrition and to continue educating parent/legal guardians about nutritional matters, in order to prevent obesity. Parents and legal guardians shape their child's lifestyle, both in quantitative and qualitative aspects of food. The literature indicates that children brought up in an authoritative manner at home usually eat more healthily, are more physically active, and have lower BMI compared to those whose upbringing is liberal and indulgent $[42,43]$.

\section{CONCLUSIONS}

1. In our own research it was shown that $78 \%$ of women breastfed their children. It is worrying that none of the examined children received mother's food until six months.

2. In our own research in children's diets we see insufficient consumption of milk and dairy products, and fish - too low a share of products rich in unsaturated fatty acids.

3. In the studied population, excessive consumption of sweets, insufficient consumption of vegetables and fruit, as well as insufficient fluid supply for age and body weight were found.

4. In the studied population, $6 \%$ of children did not consume meat at all.

5. The effect of improper diet of the studied population is malnutrition in $15 \%$ of children and overweight or obesity in $14 \%$ of children.

6. Facilitating access to a doctor and dietitian, as well as educational programs, can improve the diet of children and reduce the occurrence of diet-related diseases. 
7. There is a continuing need to increase the education of carers in expanding the infant's diet due to nutritional errors that are still occurring and are being reproduced.

\section{DISCLOSURE}

The authors report no conflict of interest.

\section{References}

1. Rios EM, Sinigaglia O, Diaz B, et al. Development of a diet quality score for infants and toddlers and its association with weight. J Nutrit Health Food Sci 2016; 4 (4): 1-7.

2. Emmett PM, Jones LR. Diet, growth, and obesity development throughout childhood in the Avon Longitudinal Study of Parents and Children. Nutr Rev 2015; 73 (53): 175-206.

3. Benuck I. Nutrition and cardiovascular health. Pediatr Ann 2013; 42 (9): 363-364.

4. Sypniewska G. Laboratory assessment of cardiometabolic risk in overweight and obese children. Clin Biochem 2015; 48 (6): 370-376.

5. Jarosz M, Rychlik E. Otyłość wyzwaniem zdrowotnym i cywilizacyjnym [Obesity - health and global challenge]. Post Nauk Med 2011; 9: 712-717.

6. Oblacińska A, Weker H. Profilaktyka otyłości u dzieci i młodzieży. Od urodzenia do dorosłości [Prevention of obesity in children and adolescents. From birth to adulthood]. Wydawnictwo Help-Med, Kraków 2008.

7. Valerio G, Licenziati MR, Manco M, et al. Health consequences of obesity in children and adolescents. Minerva Pediatr 2014; 66 (5): $381-414$

8. Sweeting HN. Measurement and definitions of obesity in childhood and adolescence a field guide for the uninitiated. Nutr J 2007; 6: 32 .

9. Kosti RI, Panagiotakos DB. The epidemic of obesity in children and adolescents in the world. Cent Eur J Public Health 2006; 14 (4): 151-159.

10. National Health Service. Statistics on obesity, physical activity and diet-England 2010. National Health Service. NHS Information Centre: The Health and Social Care Information Centre, Leeds, 2010. Available from: https://digital.nhs.uk/data-and-information/publications/statistical/statistics-on-obesity-physical-activity-and-diet/statistics-on-obesity-physical-activity-and-diet-england-2010 (accessed: 4 May 2020).

11. Department of Health. National Child Measurement Programme: England, 2009/10 school year. Department of Health: The Health and Social Care Information Centre, London 2010. Available from: https://digital.nhs.uk/data-and-information/ publications/statistical/national-child-measurement-programme/2009-10-school-year (accessed: 4 May 2020).

12. Dzielska A, Jodkowska M, Małkowska-Szkutnik, et al. Zdrowie i zachowania zdrowotne młodzieży szkolnej w Polsce. Raport z badań HBSC 2014 [Health and health behavior of school children in Poland. HBSC 2014 research report]. Available from: http://www.imid.med.pl/images/dopobrania/Zdrowie_i_zachowania_zdrowotne_www.pdf (accessed: 4 May 2020).
13. Harton A, Myszkowska-Ryciak J, Laskowski W, Gajewska D. Prevalence of overweight and obesity among adolescents in Poland. J Health Inequal 2019; 5 (2): 180-187.

14. Jarosz M. Normy żywienia dla populacji Polski [Nutrition standards for the Polish population]. Instytut Żywności i Żywienia, Warszawa 2017. Available from: https://ncez.pl/ upload/normy-net-1.pdf (accessed: 4 May 2020).

15. Dobrzańska A, Charzewska J, Weker $\mathrm{H}$, et al. Normy żywienia zdrowych dzieci w 1-3 roku życia - stanowisko Polskiej Grupy Ekspertów. Część I - Zapotrzebowanie na energię i składniki odżywcze[ Nutritional guidelines for healthy children aged 1-3 years - Polish Expert Group statement Part I - Energy and nutrient requirements]. Stand Med Pediatr 2012; 9: 100-103.

16. Dobrzańska A, Charzewska J, Weker H, et al. Normy żywienia zdrowych dzieci w 1-3 roku życia - stanowisko Polskiej Grupy Ekspertów. Część II - Omówienie poszczególnych składników odżywczych [Nutritional guidelines for healthy children aged 1-3 years - Polish Expert Group statement Part II - Description of nutrients required]. Stand Med Pediatr 2012; 9: 200-205.

17. Fewtrell M, Bronsky J, Campoy C, et al. Complementary feeding: A Position Paper by the European Society for Paediatric Gastroenterology, Hepatology, and Nutrition (ESPGHAN) Committee on Nutrition. JPGN 2017; 64 (1): 119-132.

18. Switkowski KM, Gingras V, Rifas-Shiman SL, Oken E. Patterns of Complementary Feeding Behaviors Predict Diet Quality in Early Childhood. Nutrients 2020; 12 (3): 810.

19. Ventura AK, Worobey J. Early influences on the development of food preferences. Curr Biol 2013; 23 (9): R401-408.

20. Cole TJ, Bellizzi MC, Flegal KM, Dietz WH. Establishing a standard definition for child overweight and obesity worldwide: international survey. BMJ 2000; 320 (7244): 1240-1243.

21. Forgie AJ, Drall KM, Bourque SL, et al. The impact of maternal and early life malnutrition on health: a diet-microbe perspective. BMC Med. 2020; 18: 135.

22. Michaelsen KF, Weaver L, Branca F, Robertson F. Feeding and nutrition of infants and young children. Guidelines for the WHO European Region with emphasis on the former Soviet countries. WHO regional publications, European series; No 87. Available from: http://www.euro.who.int/_data/assets/pdf_ file/0004/98302/WS_115_2000FE.pdf (accessed: 4 May 2020).

23. Bosi ATB, Eriksen KG, Sobko T, et al. Breastfeeding practices and policies in WHO European Region Member States. Public Health Nutr 2016; 19: 753-764.

24. Socha P, Grote V, Gruszfeld D, et al. European Childhood Obesity Trial Study Group: Milk protein intake, the metabolicendocrine response, and growth in infancy: data from a randomized clinical trial. Am J Clin Nutr 2011; 94 (6 Suppl): 1776S-1784S.

25. Szajewska H, Horvath A, Rybak A, Socha P. Karmienie piersią. Stanowisko Polskiego Towarzystwa Gastroenterologii, Hepatologii i Żywienia Dzieci [Breast-feeding. Stand of the Polish Society of Gastroenterology, Hepatology and Child Nutrition]. Standardy Medyczne. Pediatria 2016; 13: 9-24.

26. Grote V, von Kries R, Closa-Monasterolo R, et al. European Childhood Obesity Trial Study Group: Protein intake and growth in the first 24 months of life. J Pediatr Gastroenterol Nutr 2010; 51 (Suppl 3): S117-118. 
27. Weker H, Barańska M, Riahi A, Socha P. Kompleksowa ocena sposobu żywienia dzieci w wieku od 5 do 36 miesiąca życia badanie ogólnopolskie 2016 rok [A comprehensive assessment of the diet of children aged 5 to 36 months - a nationwide survey 2016]. Pitnuts 2016. Instytut Matki i Dziecka, Warszawa 2017.

28. Magagnin Neves A, Winck Madruga S. Complementary feeding, consumption of industrialized foods and nutritional status of children under 3 years old in Pelotas, Rio Grande do Sul, Brazil, 2016: a descriptive Epidemiol Serv Saúde 2019; 28 (1): $1-11$.

29. Clayton HB, Li R, Perrini CG, Scanlon KS. Prevalence and reason for introducing infants early to solids foods: variations by milk feeding type. Pediatrics 2013; 131 (4): e1108-1114.

30. Armstrong J, Abraham CE, Squair M, et al. Exclusive breastfeeding, complementary feeding, and food choices in UK infants. J Hum Lact 2014; 30 (2): 201-208.

31. Siega-Riz AM, Deming DM, Reidy KC, et al. Food consumption patterns of infants and toddlers: where are we now? J Am Diet Assoc. 2010; 110 (Suppl 12): 38S-51S.

32. Harton A, Florczak J, Myszkowska-Ryciak J, Gajewska D. Spożycie warzyw i owoców przez dzieci w wieku przedszkolnym [Fruit and vegetable consumption by preschool children]. Probl Hig Epidemiol 2015, 96 (4): 732-736.

33. Fox MK, Condon E, Briefel RR, et al. Food consumption patterns of young preschoolers: are they starting off on the right path? J Am Diet Assoc 2010; 110 (12Suppl): S52-S59.

34. Lioret S, McNaughton SA, Spence AC, et al. Tracking of dietary intakes in early childhood: the Melbourne InFANT Program. Eur J Clin Nutr 2013; 67 (3): 275-281.

35. Chan L, Magarey AM, Daniels LA. Maternal feeding practices and feeding behaviors of Australian children aged 12-36 months. Matern Child Health J 2011; 15 (8): 1363-1371.

36. Amezdroz E, Carpenter L, O’Callaghan E, et al. Transition from milks to the introduction of solid foods across the first 2 years of life: findings from an Australian birth cohort study. J Hum Nutr Diet 2015; 28 (4): 375-383

37. Woś H, Weker H, Jackowska T, et al. Stanowisko Grupy Ekspertów w sprawie zaleceń dotyczących spożycia wody i innych napojów przez niemowlęta, dzieci i młodzież [Position paper of the expert group on intake of drinking water and other beverages by infants, children and youth]. Stand Med Interna 2010, 1: 7-15.

38. Budree S, Goddard E, Brittain K, et al. Infant feeding practices in a South African birth cohort - a longitudinal study. Matern Child Nutr 2017; 13 (3): e12371.

39. Miles G, Siega-Riz AM. Trends in food and beverage consumption among infants and toddlers: 2005-2012. Pediatrics 2017; 139 (6): e20163290.

40. Weker H, Barańska M, Riahi A, et al. Wzory żywienia niemowląt i małych dzieci - badanie ogólnopolskie [Dietary patterns of infants and children aged 13-36 months - nationwide study]. Stand Med Pediatr 2014; 11: 417-427.

41. Druet C, Stettler N, Sharp S, et al. Prediction of childhood obesity by infancy weight gain: an individual-level meta-analysis. Paediatr Perin Epidemiol 2011; 26 (1): 19-26.
42. Rivera-Soto WT, Rodríguez-Figueroa L. Childhood obesity among Puerto Rican children: discrepancies between child's and parent's perception of weight status. Int J Environ Res Public Health 2012; 9 (4): 1427-1437.

43. Towns N, D'Auria J. Parental perceptions of their child's overweight: An integrative review of the literature. J Pediatr Nurs 2009; 24 (2): 115-130.

\section{AUTHORS' CONTRIBUTIONS}

PWB, HK, and ZCM prepared research concept and design of the publication. PWB, KK, HK, and LKS collected data, analysed, and interpreted. PWB and HK wrote the article. LKS and HK critically revised it. PWB and HK contributed to preparing the final publication. 